\title{
mRNA abundance of genes involved in mammary lipogenesis during fish oil- or trans-10, cis-12 CLA-induced milk fat depression in dairy ewes
}

\author{
P. G. Toral, G. Hervás, ${ }^{1}$ A. Belenguer, D. Carreño, and P. Frutos \\ Instituto de Ganadería de Montaña (CSIC-Universidad de León), Finca Marzanas s/n, 24346 Grulleros, León, Spain
}

\begin{abstract}
Milk fat depression (MFD) caused by trans-10, cis-12 18:2 is known to be mediated in cows and ewes by downregulation of mammary lipogenic genes. However, transcriptional mechanisms underlying marine lipidinduced MFD have not been well defined yet and the few available studies in ovine are not consistent. This trial was conducted to directly compare changes in animal performance, milk fatty acid composition, and particularly mammary mRNA abundance of candidate lipogenic genes and transcription factors in response to the inclusion of fish oil or trans-10,cis-12 18:2 in the dairy sheep diet. To meet this objective, 12 lactating Assaf ewes (on average, 64 days in milk, producing 1.72 $\mathrm{kg}$ of milk/d with $5.17 \%$ of fat) were divided into 3 groups and offered a total mixed ration without supplementation (control) or supplemented with $2.4 \%$ dry matter of fish oil (FO treatment) or 1\% dry matter of a commercial product rich in trans-10,cis-12 18:2 (CLA treatment) for $39 \mathrm{~d}$. Measurements and samplings were conducted before starting the treatments and at the end of the trial. Milk samples were used for RNA extraction from somatic cells. Feed intake was not affected by lipid supplements, and as designed, reductions in milk fat concentration $(-31 \%)$ were similar in the 2 treatments, although the unpredicted increase in milk production with FO counteracted the anticipated reduction in milk fat yield. Nevertheless, this did not preclude the detection of FO-induced decreases in the mRNA abundance of candidate lipogenic genes [e.g., acyl-CoA synthetase short-chain family member 2 (ACSS2), fatty acid synthase $(F A S N)$, and lipin 1 (LPIN1)], thus supporting the hypothesis that transcriptional regulation would be a relevant component of this type of MFD in sheep. Expected CLA-induced downregulation of some genes, such as $F A S N$ or sterol regulatory element binding transcription factor 1 (SREBF1), could not be detected in our samples, which might be related,
\end{abstract}

Received August 1, 2016.

Accepted November 26, 2016.

${ }^{1}$ Corresponding author: g.hervas@csic.es at least in part, to high inter-individual variation and relatively advanced lactation stage (on average 102-103 $\mathrm{d}$ in milk on d 38 and 39). Overall, direct comparison of the effects of dietary FO and CLA on transcript abundance of candidate lipogenic genes and transcription factors suggest that there might be relevant differences in the transcriptional control mechanisms underlying the MFD induced by each kind of supplement (i.e., fish oil or CLA).

Key words: fatty acid, gene expression, marine lipid, nutrigenomics, sheep

\section{INTRODUCTION}

Due to the great economic value of milk fat for the dairy industry, diet-induced milk fat depression (MFD) represents a major obstacle for the implementation of some feeding strategies aimed at modulating milk fatty acid (FA) profile, especially in small ruminants (Chilliard et al., 2007; Toral et al., 2010). This constraint has encouraged targeted research to unravel the mechanisms underlying the nutritional regulation of mammary lipogenesis (Shingfield et al., 2010; Bionaz et al., 2015).

Compared with the relatively well characterized MFD caused by high-concentrate diets and plant oils (e.g., Peterson et al., 2003; Mach et al., 2011), the effects of marine lipids on milk fat synthesis are still poorly understood (Ahnadi et al., 2002; Bichi et al., 2013; Vahmani et al., 2014). Feeding starch-rich diets and 18-carbon PUFA to dairy cows increases the ruminal outflow of the trans-10,cis-12 isomer of CLA, which is known to downregulate key genes and transcription factors involved in lipid metabolism in the mammary gland, such as acetyl-CoA carboxylase alpha $(A C A C A)$, fatty acid synthase $(F A S N)$, or sterol regulatory element binding transcription factor 1 (SREBF1; Bernard et al., 2008; Bauman et al., 2011). Although dairy ewes are not prone to this type of diet-induced MFD (Mele et al., 2006; Castro-Carrera et al., 2015), they are sensitive to the antilipogenic activity of trans-10, cis-12 $18: 2$, which also appears to be mediated by changes in mammary gene expression in this species (Hussein 
et al., 2013; Ticiani et al., 2016). However, the causes and mechanisms underlying marine lipid-induced MFD (affecting both dairy cows and ewes) have not been well defined yet (Ahnadi et al., 2002; Bichi et al., 2013; Toral et al., 2016a). Interestingly, direct comparison of milk FA profiles from lactating sheep fed fish oil or trans-10,cis-12 18:2 supplements (Toral et al., 2015) suggested that their inhibitory effects on milk fat synthesis might share common mechanisms. An explanation of marine lipid-induced MFD based on a downregulation of lipogenic gene expression seems therefore reasonable in ovine, but the few available studies on this subject are inconsistent (Bichi et al., 2013; Carreño et al., 2016).

Thus, this study was conducted to directly compare changes in milk composition, including the FA profile, and mammary mRNA abundance of candidate lipogenic genes and related transcription factors in response to the dietary inclusion of fish oil or a rumen-protected product rich in trans-10,cis-12 18:2 in dairy ewes.

\section{MATERIALS AND METHODS}

\section{Animals, Experimental Design, and Management}

All experimental procedures were approved and completed in accordance with the Spanish Royal Decree $53 / 2013$ for the protection of animals used for experimental purposes. Twelve lactating Assaf ewes (82.7 \pm $1.98 \mathrm{~kg} ; \mathrm{DIM}=64 \pm 1.9$; parity $=2.3 \pm 0.30 ;$ milk yield $=1.72 \pm 0.135 \mathrm{~kg} / \mathrm{d}$ ) were housed in individual tie stalls and randomly allocated to 1 of 3 dietary treatments $(\mathrm{n}=4)$ : a TMR (forage:concentrate ratio 40:60) without lipid supplementation (control) or supplemented with $2.4 \%$ DM of fish oil (FO treatment) or $1 \%$ DM of a rumen-protected CLA product (Lutrell Pure, BASF, Ludwigshafen, Germany; CLA treatment). The ingredients of the experimental diets, which were prepared weekly and included molasses to reduce selection of components, and a detailed FA profile of the lipid supplements, are presented in Table 1. All ewes had been fed the control diet for a 22-d adaptation period, and both experimental diets were then offered daily ad libitum, at approximately 0900 and $1900 \mathrm{~h}$, for 39 more days. Refusals were removed and weighed each morning, and clean water was always available. Ewes were milked twice daily at 0830 and $1830 \mathrm{~h}$ in a single-side milking parlor with 10 stalls (DeLaval, Madrid, Spain).

\section{Measurements and Sampling Procedures}

At the end of the adaptation period ( $\mathrm{d}-5$ and -3 ), and after 35 and $37 \mathrm{~d}$ on treatments, milk yield was recorded and individual milk samples were collected and composited according to morning and evening milk yield. One aliquot of composite milk was preserved with bronopol (D\&F Control Systems Inc., San Ramon, CA) and stored at $4^{\circ} \mathrm{C}$ until analyzed for fat, CP, and TS concentrations. Milk FA composition was determined in untreated samples stored at $-30^{\circ} \mathrm{C}$ until analysis.

Total RNA was isolated from somatic cells in milk samples collected before starting the experiment $(\mathrm{d}-2$ and -1 ) and after 38 and $39 \mathrm{~d}$ on treatments (Toral et al., 2016b). Following the protocol by Suárez-Vega et al. (2015), approximately $1 \mathrm{~h}$ after milking, when ewe milk contains the greatest number of somatic cells (Gonzalo et al., 1994), animals received an injection of oxytocin (5 IU/animal; Facilpart, Laboratorios SYVA, León, Spain). Udders were cleaned with water and soap and then disinfected with povidone iodine, and nipples were also washed with RNaseZap (Ambion, Austin, TX). Individual samples were collected $10 \mathrm{~min}$ after the injection of oxytocin by hand-milking both halves of the mammary gland into an RNase-free $50-\mathrm{mL}$ tube, which was covered with a sterile gauze to filter the milk. Samples were held in ice and transferred immediately to the laboratory for RNA extraction.

\section{Laboratory Analysis}

Diets and Orts. Dry matter concentration in diets and orts was determined according to the ISO (1999a) standard. Diets were also analyzed for ash (ISO, 2002) and CP (ISO, 2009). The NDF and ADF were determined using an Ankom ${ }^{2000}$ fiber analyzer (Ankom Technology Methods 13 and 12, respectively; Ankom Technology Corp., Macedon, NY); the former was assayed with sodium sulfite and $\alpha$-amylase, and both were expressed with residual ash. Fatty acid methyl esters of lipid in freeze-dried diets were prepared in a 1-step extraction-transesterification procedure using chloroform (Sukhija and Palmquist, 1988) and 2\% (vol/ vol) sulfuric acid in methanol (Shingfield et al., 2003), and cis-12 tridecenoate (Larodan, Solna, Sweden) as an internal standard. Methyl esters were separated and quantified using a gas chromatograph (Agilent 7890A GC System, Santa Clara, CA) equipped with a flameionization detector and a 100-m fused silica capillary column $(0.25 \mathrm{~mm}$ i.d., $0.2-\mu \mathrm{m}$ film thickness; CP-SIL 88, CP7489, Varian Ibérica S.A., Madrid, Spain) and hydrogen as the carrier gas $(207 \mathrm{kPa}, 2.1 \mathrm{~mL} / \mathrm{min})$. Total FAME profile in a $2-\mu \mathrm{L}$ sample volume at a split ratio of 1:50 was determined using the temperature gradient program described in Shingfield et al. (2003). Peak identification was based on retention time comparisons with commercially available standard FAME mixtures (from Nu-Chek Prep, Elysian, MN; and Sigma-Aldrich, Madrid, Spain). 
Milk. Milk fat, CP, and TS concentrations were determined by infrared spectrophotometry (ISO, 1999b) using a MilkoScan FT6000 (Foss, Hillerød, Denmark). Lipid in $1 \mathrm{~mL}$ of milk was extracted using diethylether and hexane $(5: 4, \mathrm{vol} / \mathrm{vol})$ and converted to FAME by base catalyzed transesterification (Shingfield et al., 2003). The total FAME profile was determined by gas chromatography using the same chromatograph and temperature gradient program applied for the analysis of feeds, but isomers of 18:1 were further resolved in a separate analysis under isothermal conditions at $170^{\circ} \mathrm{C}$ (Shingfield et al., 2003). Peak identification was based on retention time comparisons with the same FAME mixtures used for the analysis of feeds, other commercially available standards (from Nu-Chek Prep, SigmaAldrich, and Larodan), and comparison with reference samples for which the FA composition was determined based on gas chromatography analysis of FAME and GC-MS analysis of corresponding 4,4-dimethyloxazoline derivatives.

RNA Isolation and Quantitative PCR. Total RNA in $50 \mathrm{~mL}$ of fresh milk was extracted as described by Wickramasinghe et al. (2012), with modifications reported by Suárez-Vega et al. (2015). Briefly, milk somatic cells were pelleted by centrifugation at $650 \times$ $g$ for $10 \mathrm{~min}$ at $4^{\circ} \mathrm{C}$ in the presence of a final concentration of $0.5 \mathrm{~m} M$ EDTA. The cell pellet was washed with $10 \mathrm{~mL}$ of PBS (pH 7.2 and $0.5 \mathrm{~m} M$ EDTA) followed by another centrifugation at $650 \times g$ for $10 \mathrm{~min}$ at $4^{\circ} \mathrm{C}$. The washing and centrifugation procedure was repeated twice by using 2 and $1.5 \mathrm{~mL}$ of the same PBS solution. Total RNA was then extracted and purified from the milk cell pellet with TRIzol (Invitrogen, Carlsbad, CA).

Table 1. Formulation and chemical composition of the TMR without lipid supplementation (control) or supplemented with $2.4 \% \mathrm{DM}$ of fish oil (FO) or 1\% DM of a product rich in trans-10,cis-12 18:2 (CLA)

\begin{tabular}{|c|c|c|c|}
\hline \multirow[b]{2}{*}{ Item } & \multicolumn{3}{|c|}{ TMR } \\
\hline & Control & FO & CLA \\
\hline \multicolumn{4}{|l|}{ Ingredient, $\mathrm{g} / \mathrm{kg}$ of fresh matter } \\
\hline Dehydrated alfalfa hay, particle size $>4 \mathrm{~cm}$ & 400 & 391 & 396 \\
\hline Whole corn grain & 180 & 176 & 178 \\
\hline Whole barley grain & 130 & 127 & 129 \\
\hline Soybean meal solvent, $440 \mathrm{~g}$ of $\mathrm{CP} / \mathrm{kg}$ & 150 & 147 & 149 \\
\hline Sugar beet pulp, pellets & 70 & 68 & 69 \\
\hline Molasses, liquid & 50 & 49 & 50 \\
\hline Fish oil $^{1}$ & 0 & 22 & 0 \\
\hline Rumen-protected CLA product ${ }^{2}$ & 0 & 0 & 10 \\
\hline Vitamin-mineral supplement ${ }^{3}$ & 20 & 20 & 20 \\
\hline \multicolumn{4}{|l|}{ Chemical composition, $\mathrm{g} / \mathrm{kg}$ of DM } \\
\hline OM & 902 & 901 & 901 \\
\hline $\mathrm{CP}$ & 176 & 171 & 171 \\
\hline NDF & 305 & 306 & 306 \\
\hline $\mathrm{ADF}$ & 208 & 209 & 209 \\
\hline Starch & 171 & 167 & 167 \\
\hline Total fatty acids & 18.2 & 40.3 & 26.1 \\
\hline 14:0 & 0.24 & 1.14 & 0.24 \\
\hline 16:0 & 3.91 & 8.20 & 4.76 \\
\hline cis-9 16:1 & 0.04 & 1.06 & 0.04 \\
\hline 18:0 & 0.80 & 1.93 & 4.80 \\
\hline cis-9 18:1 & 2.89 & 6.66 & 4.08 \\
\hline cis-11 18:1 & 0.22 & 0.95 & 0.29 \\
\hline $18: 2 \mathrm{n}-6$ & 6.78 & 7.26 & 6.89 \\
\hline cis-9,trans-11 18:2 & 0.00 & 0.00 & 0.93 \\
\hline trans-10,cis-12 18:2 & 0.00 & 0.00 & 0.92 \\
\hline $18: 3 n-3$ & 2.22 & 2.39 & 2.24 \\
\hline $20: 5 n-3$ & 0.00 & 1.49 & 0.00 \\
\hline $22: 5 n-3$ & 0.00 & 0.34 & 0.00 \\
\hline $22: 6 n-3$ & 0.00 & 4.55 & 0.00 \\
\hline
\end{tabular}

${ }^{1}$ Semirefined tuna and sardine oil (Afampes 121 DHA, Afamsa, Mos, Spain) contained (g/kg of total fatty acids) 14:0 (40), 16:0 (192), cis-9 16:1 (45), 17:0 (15), 18:0 (50), cis-9 18:1 (168), cis-11 18:1 (32), 18:2n-6 (28), 18:3n-3 (10), cis-11 20:1 (18), 20:5n-3 (65), 22:5n-3 (15), and 22:6n-3 (199).

${ }^{2}$ Lutrell Pure (BASF, Ludwigshafen, Germany) contained (g/kg of total fatty acids) 16:0 (98), 18:0 (501), cis-9 18:1 (155), cis-9,trans-11 18:2 (104), trans-10,cis-12 18:2 (107), and $807 \mathrm{~g}$ of total fatty acids/kg of DM. ${ }^{3}$ MACROFAC Rumiantes (UP911755130; DSM Nutritional Products S.A., Madrid, Spain). Declared as containing Ca $(285 \mathrm{~g} / \mathrm{kg}), \mathrm{Na}(7.5 \mathrm{~g} / \mathrm{kg}), \mathrm{Fe}(3 \mathrm{~g} / \mathrm{kg}), \mathrm{Mn}(3 \mathrm{~g} / \mathrm{kg}), \mathrm{Zn}(2 \mathrm{~g} / \mathrm{kg}), \mathrm{Mg}(1 \mathrm{~g} / \mathrm{kg}), \mathrm{P}(910 \mathrm{mg} / \mathrm{kg}), \mathrm{Mo}$ (100 mg/kg), Co $(67 \mathrm{mg} / \mathrm{kg})$, I (50 mg/kg), S (40 mg/kg), Se $(7 \mathrm{mg} / \mathrm{kg})$, vitamin A $(200,000 \mathrm{IU} / \mathrm{kg})$, vitamin $\mathrm{D}_{3}(40,000 \mathrm{IU} / \mathrm{kg})$, vitamin $\mathrm{E}(667 \mathrm{mg} / \mathrm{kg})$, ethoxyquin $(12 \mathrm{mg} / \mathrm{kg})$, and propyl gallate $(2 \mathrm{mg} / \mathrm{kg})$. 
Table 2. Candidate genes analyzed in milk somatic cells (data on primer sequences and quantitative PCR performance are reported in Supplemental Table S1; https://doi.org/10.3168/jds.2016-11814)

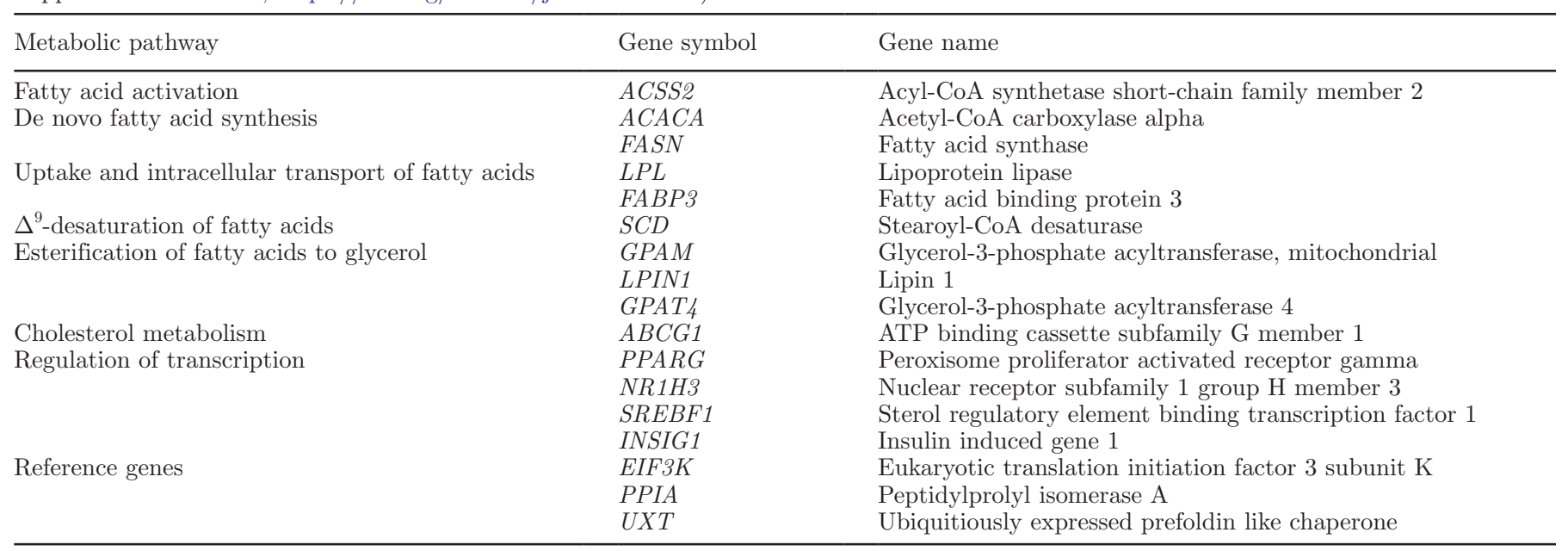

The RNA concentration was determined by fluorometry (Qubit 3.0, Life Technologies, Carlsbad, CA), and RNA integrity number by capillary electrophoresis (Agilent 2100 Bioanalyzer, Agilent Technologies Inc.). The average RNA integrity number of the samples was $7.64 \pm 0.090$. For quantitative PCR (qPCR) analysis, cDNA was synthesized through the High Capacity RNA-to-cDNA Kit (Applied Biosystems, Foster City, $\mathrm{CA})$. The qPCR was carried out as described in Bonnet et al. (2013) using a 7500 Real-Time PCR System (Applied Biosystems) and specific primers for the main candidate lipogenic genes involved in milk fat synthesis and the transcription factors that may regulate their expression (Bernard et al., 2008; Bauman et al., 2011; Bionaz et al., 2015). These genes are described in Table 2 and were selected on the basis of previous works on lipid metabolism in ruminants (e.g., Bauman et al., 2011; Hussein et al., 2013; Carreño et al., 2016). To account for variations in RNA integrity and quantification and cDNA synthesis, mRNA abundance was normalized using the geometric mean of 3 reference genes: eukaryotic translation initiation factor 3 subunit K (EIF3K), peptidylprolyl isomerase A (PPIA), and ubiquitously expressed prefoldin like chaperone $(U X T)$, which have been identified as suitable internal controls (Bionaz and Loor, 2007; Bonnet et al., 2013). Gene stability was examined using the geNorm procedure (Vandesompele et al., 2002) and the lack of DNA contamination was verified by PCR amplification with primers flanking an intron (e.g., EIF3K and INSIG1). The primer sequences and qPCR performance are shown in Supplemental Table S1 (https://doi.org/10.3168/jds.2016-11814). The abundance of gene transcripts was calculated using a 5-point calibration curve generated from the serial dilution of a cDNA pool, prepared by mixing equal volumes of all samples, and was expressed as the $\log _{2}$ value of mRNA copy number relative to the geometric mean of the 3 reference genes.

\section{Calculations and Statistical Analysis}

All statistical analyses were performed using the SAS software package (version 9.4, SAS Institute Inc., Cary, NC). Data were analyzed by one-way ANCOVA with a model that included the fixed effect of experimental diet (mean values over d 35 and 37 for animal performance and milk FA composition, and d 38 or 39 for transcript mRNA abundances) and measurements at the end of the adaptation period (mean values over $\mathrm{d}-5$ and -3 for animal performance and milk FA composition, and $\mathrm{d}-2$ or -1 for transcript mRNA abundances) as a covariate. In all cases, animals were nested within the treatment and used as the error term to contrast the effect of treatments. Means were separated through the "pdiff" option of the "lsmeans" statement of the MIXED procedure, adjusting for multiple comparisons using Bonferroni's method. Differences were declared significant at $P<0.05$ and considered a trend toward significance at $P<0.10$. Least squares means are reported.

\section{RESULTS}

\section{Animal Performance and Milk Composition and FA Profile}

Diet supplementation with fish oil or the CLA-rich product decreased milk fat concentration similarly (on average, $-31 \%$, compared with the control; $P<0.001$; Table 3). Milk fat yield was also negatively affected 
Table 3. Intake and milk yield and composition in dairy ewes fed a TMR without lipid supplementation (control) or supplemented with $2.4 \% \mathrm{DM}$ of fish oil (FO) or 1\% DM of a product rich in trans-10,cis-12 18:2 (CLA)

\begin{tabular}{lccccr}
\hline & \multicolumn{3}{c}{ Treatment } & & \\
\cline { 2 - 3 } Item & Control & FO & CLA & SED $^{1}$ & $P_{\text {-value }}^{2}$ \\
\hline DMI, g/d & 2,797 & 2,651 & 2,603 & 250.0 & 0.731 \\
Milk, g/d & $1,438^{\mathrm{b}}$ & $1,896^{\mathrm{a}}$ & $1,413^{\mathrm{b}}$ & 141.8 & 0.015 \\
Fat, \% & $5.91^{\mathrm{a}}$ & $4.22^{\mathrm{b}}$ & $3.98^{\mathrm{b}}$ & 0.270 & $<0.001$ \\
g/d & $82.5^{\mathrm{a}}$ & $79.9^{\mathrm{a}}$ & $57.5^{\mathrm{b}}$ & 4.51 & 0.001 \\
CP, \% & 4.99 & 4.57 & 4.84 & 0.215 & 0.197 \\
g/d & $70.7^{\mathrm{ab}}$ & $86.8^{\mathrm{a}}$ & $67.2^{\mathrm{b}}$ & 6.36 & 0.031 \\
TS, \% & $16.68^{\mathrm{a}}$ & $14.78^{\mathrm{b}}$ & $14.56^{\mathrm{b}}$ & 0.417 & 0.002 \\
g/d & $236.6^{\mathrm{ab}}$ & $279.6^{\mathrm{a}}$ & $206.7^{\mathrm{b}}$ & 20.29 & 0.020 \\
\hline
\end{tabular}

${ }^{a, b}$ Within a row, different superscripts indicate significant differences $(P<0.05)$.

${ }^{1} \mathrm{SED}=$ standard error of the difference.

${ }^{2}$ Probability of significant effects due to dietary treatment.

by CLA $(P<0.01)$, whereas FO had no effect on this parameter due to the $33 \%$ increase in milk yield in this treatment $(P<0.05)$. Both lipid supplements reduced TS concentration $(-12 \%$ relative the control; $P<0.05)$ but did not affect DMI or milk protein $(P>0.10)$. The average trans-10,cis-12 18:2 intake in the CLA group was $2.4 \mathrm{~g} / \mathrm{d}$.

As expected, feeding fish oil increased $(P<0.05)$ the milk concentration of most of its constituent FA, especially very long-chain FA such as 20:5n-3, 22:5n-3, and 22:6n-3 (Table 4). Likewise, only the CLA treatment induced an increase $(P<0.001)$ in the proportion of trans-10,cis-12 18:2 in milk fat.

Besides these variations in the FA provided by the supplements, different changes in milk FA profiles were observed for each treatment (Table 4 and Supplemental Table S2; https://doi.org/10.3168/jds.2016-11814), and for example, the concentration of even-chain SFA with 6 to 12 carbons was lower $(P<0.01)$ in CLA than in FO, whereas the opposite was found for some oddand branched-chain FA (i.e., iso 14:0, 15:0 and anteiso 15:0) and particularly 18:0 and cis-9 18:1 $(P<0.05)$. Feeding FO multiplied the proportion of keto-FA (i.e., 8-oxo-16:0 and 10-oxo-18:0; $P<0.001)$ in milk and was also associated with greater $(P<0.05)$ concentrations of most trans FA (e.g., trans-9 16:1, trans-11 18:1, and cis-9,trans-11 18:2) and a few cis MUFA (e.g., cis-9 10:1) than CLA.

\section{mRNA Abundance of Candidate Genes}

The transcript abundance of the 3 reference genes (EIF3K, PPIA, and UXT) was unaffected by lipid supplementation $(P>0.10)$ and their stability was the greatest among the set of quantified genes.
The mRNA relative abundances of candidate lipogenic genes and related transcription factors in milk somatic cells are reported in Figures 1 and 2. Compared with the control, FO downregulated acyl-CoA synthetase short-chain family member 2 (ACSS2) and FASN $(P<0.05)$, whereas multiple comparisons did not allow detection of statistical differences between CLA and the other treatments $(P>0.10$; Figure 1$)$. Despite the $P$-value $<0.10$ for the effect of experimental diets on the transcript abundance of $A C A C A$, no significant differences among groups were detected after Bonferroni adjustment. Supplementation with the marine lipid reduced the mRNA abundance of lipin 1 (LPIN1) compared with the control, and values for lipoprotein lipase $(L P L)$ and $L P I N 1$ were lower $(P<0.05)$ in FO than in CLA.

The inclusion of rumen-protected CLA in the TMR tended to upregulate glycerol-3-phosphate acyltransferase 4 (GPAT4) and ATP binding cassette subfamily $\mathrm{G}$ member $1(A B C G 1)$ genes $(P<0.10$; Figure 1$)$, relative to the control. However, mean abundances in ewes fed FO did not differ from those quantified in the other dietary treatments $(P>0.10)$.

Concerning transcription factors (Figure 2), the mRNA abundance of peroxisome proliferator activated receptor gamma $(P P A R G ; P<0.05)$ and nuclear receptor subfamily 1 group $\mathrm{H}$ member $3(N R 1 H 3 ; P<0.10)$ was higher in ewes receiving CLA. The expression of insulin induced gene 1 (INSIG1) tended to be lower in FO than in CLA $(P<0.10)$, although none of them was different from the control after multiple testing correction.

Finally, no variations $(P>0.10)$ were detected in the abundance levels of the lipogenic genes fatty acid binding protein 3 (FABP3), stearoyl-CoA desaturase $(S C D)$, and glycerol-3-phosphate acyltransferase, mito- 
Table 4. Milk fatty acid (FA) composition in dairy ewes fed a TMR without lipid supplementation (control) or supplemented with $2.4 \%$ DM of fish oil (FO) or 1\% DM of a product rich in trans-10,cis-12 18:2 (CLA; data on additional FA are reported in Supplemental Table S2; https:// doi.org/10.3168/jds.2016-11814)

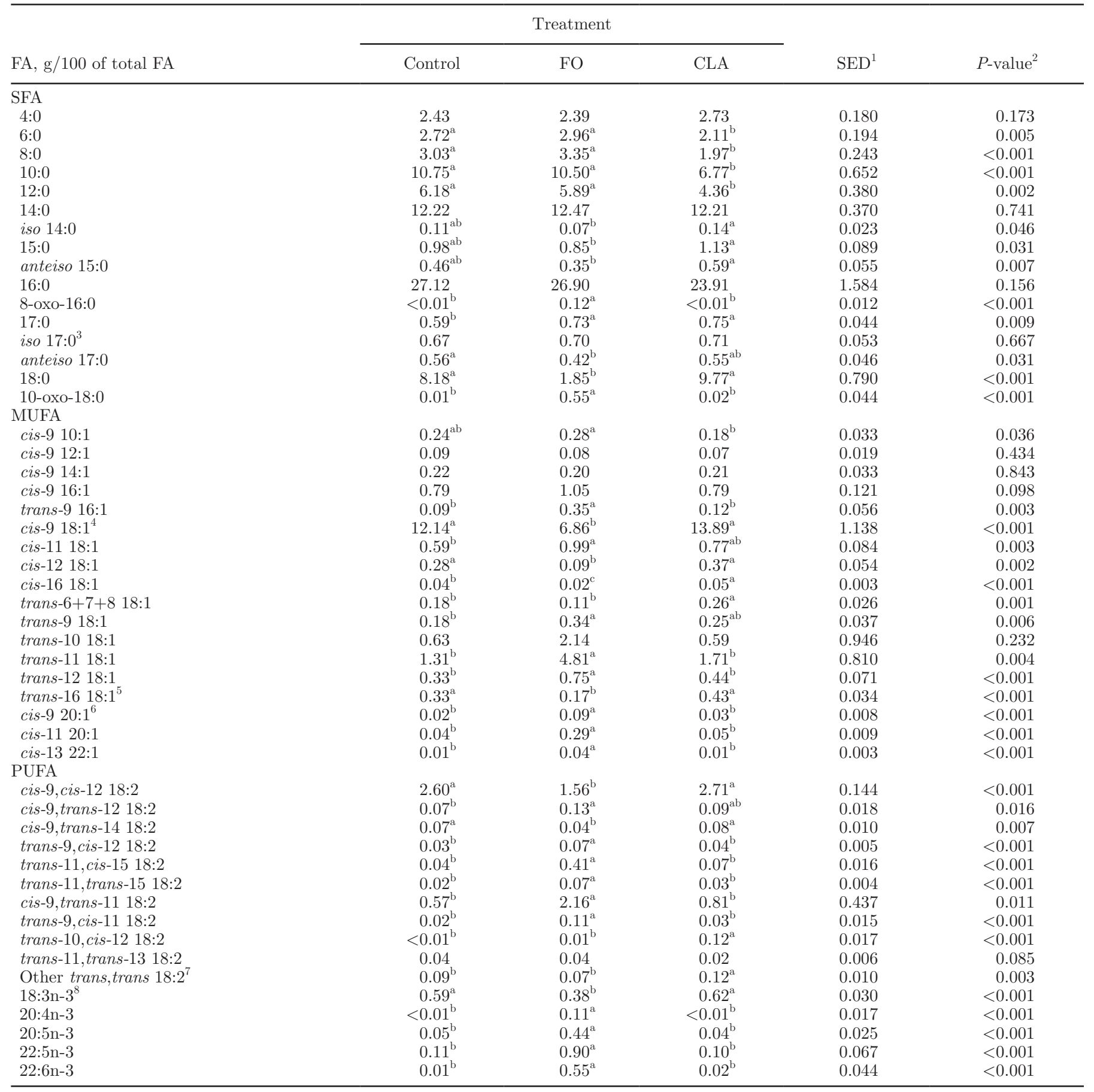

${ }^{\mathrm{a}-\mathrm{c}}$ Within a row, different superscripts indicate significant differences $(P<0.05)$.

${ }^{1} \mathrm{SED}=$ standard error of the difference.

${ }^{2}$ Probability of significant effects due to dietary treatment.

${ }^{3}$ Coelutes with cis-7 16:1.

${ }^{4}$ Contains trans-13+14 18:1 as minor components.

${ }^{5}$ Coelutes with cis-14 18:1.

${ }^{6}$ Coelutes with 20:1 of indeterminant double-bond position.

${ }^{7}$ Sum of trans-8 trans-10, trans-9 trans-11, and trans-10 trans-12 18:2. Coelutes with 21:0.

${ }^{8}$ Contains trans-11 20:1 as a minor component. 


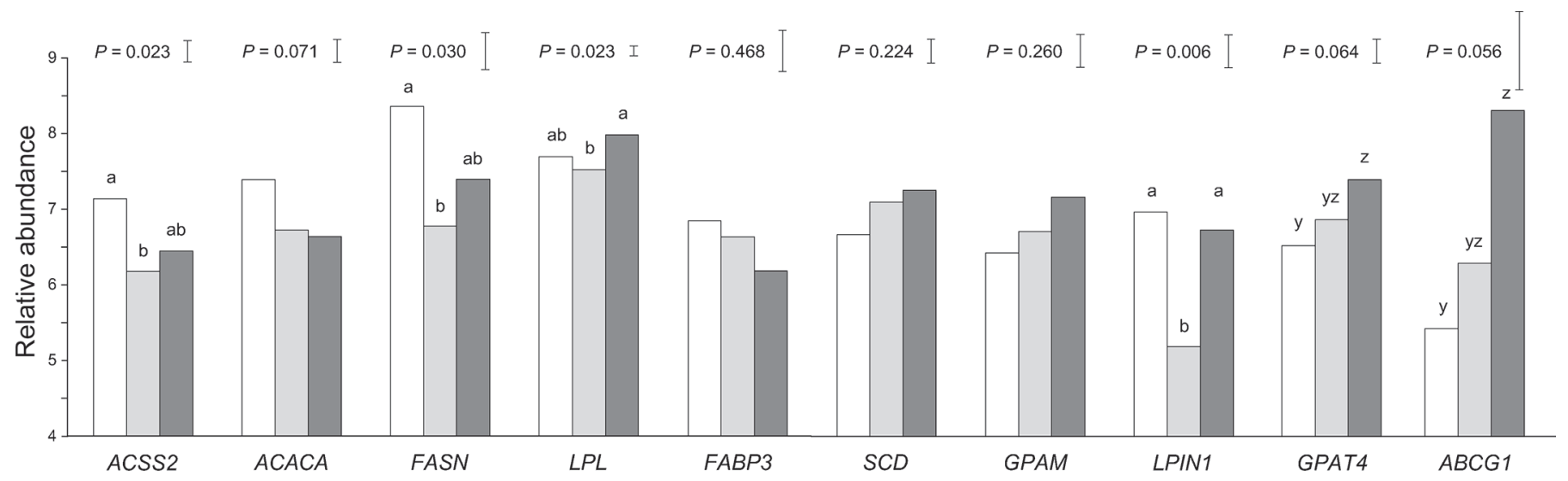

Figure 1. The mRNA relative abundance ( $\log _{2}$ transformed data; arbitrary units) of lipogenic genes in milk somatic cells in dairy ewes fed a TMR without lipid supplementation (control; white bars) or supplemented with $2.4 \%$ DM of fish oil (FO; light gray bars) or 1\% DM of a product rich in trans-10,cis-12 18:2 (CLA; dark gray bars). Vertical bars represent the SE of the difference for treatment effects. Within a gene, different letters indicate significant differences $\left({ }^{\mathrm{a}, \mathrm{b}} P<0.05\right)$ or a tendency to significance $\left({ }^{\mathrm{y}, \mathrm{z}} P<0.10\right)$. ACSS2 $=$ acyl-CoA synthetase shortchain family member 2; $A C A C A=$ acetyl-CoA carboxylase alpha; $F A S N=$ fatty acid synthase; $L P L=$ lipoprotein lipase; $F A B P 3=$ fatty acid binding protein $3 ; S C D=$ stearoyl-CoA desaturase; GPAM = glycerol-3-phosphate acyltransferase, mitochondrial; LPIN1 = lipin 1; GPAT4 $=$ glycerol-3-phosphate acyltransferase $4 ; A B C G 1=$ ATP binding cassette subfamily $\mathrm{G}$ member 1 .

chondrial (GPAM; Figure 1) and the SREBF1 transcription factor (Figure 2).

\section{DISCUSSION}

The scientific literature on nutrigenomics in lactating ruminants (e.g., Bauman et al., 2011; Bionaz et al., 2015) provides strong evidence of the relevance of

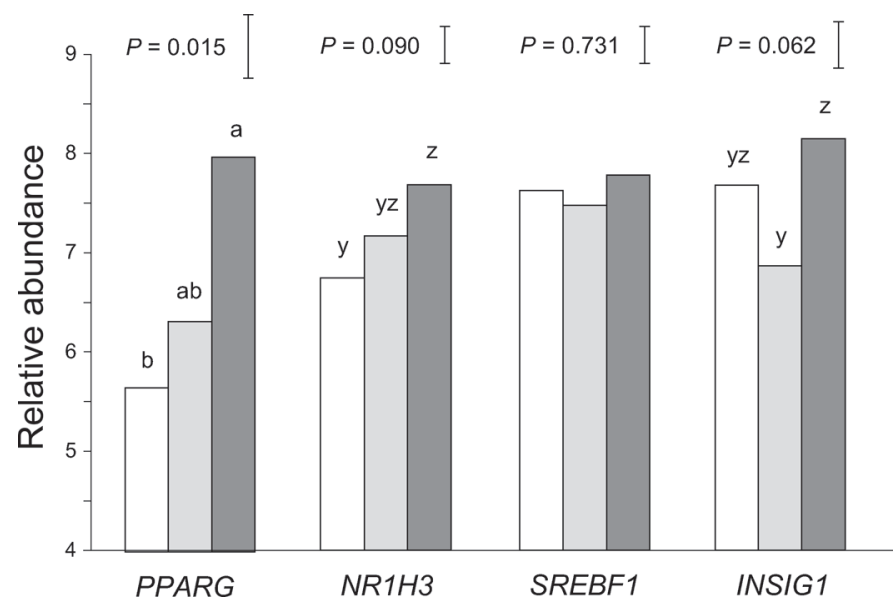

Figure 2. The mRNA relative abundance $\left(\log _{2}\right.$ transformed data; arbitrary units) of transcription factors in milk somatic cells in dairy ewes fed a TMR without lipid supplementation (control; white bars) or supplemented with $2.4 \%$ DM of fish oil (FO; light gray bars) or $1 \%$ DM of a product rich in trans-10,cis-12 18:2 (CLA; dark gray bars). Vertical bars represent the SE of the difference for treatment effects. Within a gene, different letters indicate significant differences $\left({ }^{\mathrm{a}, \mathrm{b}} P<\right.$ $0.05)$ or a tendency to significance $\left({ }^{y, z} P<0.10\right)$. PPARG $=$ peroxisome proliferator activated receptor gamma; $N R 1 H 3=$ nuclear receptor subfamily 1 group $\mathrm{H}$ member 3 ; SREBF1 = sterol regulatory element binding transcription factor $1 ;$ INSIG1 = insulin induced gene 1 . transcriptional control mechanisms in trans-10,cis-12 18:2-induced MFD. Nonetheless, mechanisms driving marine lipid-induced MFD are less well characterized and still uncertain in ruminants in general and sheep in particular (Ahnadi et al., 2002; Bichi et al., 2013; Carreño et al., 2016).

In this study, both lipid supplements were intended to induce an equivalent MFD to facilitate direct comparisons in terms of transcript mRNA abundances. Thus, as designed, reductions in milk fat concentration $(-31 \%)$ were similar with both treatments and in the upper range observed in ewes, seldom exceeding a decrease of $30 \%$ (Toral et al., 2015; Carreño et al., 2016; Ticiani et al., 2016). The higher milk production caused by FO supplementation was unexpected, and counteracted the reduction in milk fat yield, in contrast with our earlier experiment using the same supplements (Toral et al., 2015). In the absence of changes in DMI, it could be anticipated that the greater energy content of oil-supplemented diets would increase milk yield, but treatment with marine lipids has shown contrasting responses in this parameter both in ewes and cows (e.g., Keady et al., 2000; Ahnadi et al., 2002; Toral et al., 2016a), probably due to inter-individual differences in the sensitivity to the effects of these supplements. In any event, despite the inconsistency in milk yield compared with our previous study (Toral et al., 2015), both trials showed rather uniform differences between FO and CLA treatments in milk FA composition, such as those observed for even-, odd-, and branched-chain SFA and 16:1, 18:1, and 18:2 isomers. Changes in milk FA profile and potential associations with MFD are necessary to study the transcriptional regulation of the 
process. Yet, they have been widely discussed in earlier publications of our team (e.g., Toral et al., 2010, 2015, 2016a) and will only be mentioned briefly. Thus, our results support the hypotheses that changes in milk fat fluidity would not be a major mechanism responsible for FO-induced MFD in ewes and that less well-known potentially antilipogenic metabolites (e.g., certain FA supplied with FO, intermediates of altered 18:3n-3 biohydrogenation pathways, or oxo-FA; Toral et al., 2015, 2016a; Carreño et al., 2016) would probably be involved.

Examination of published studies in ovine suggests that performance and milk FA responses to trans10,cis-12 18:2 are reasonably consistent (Hussein et al., 2013; Toral et al., 2015; Ticiani et al., 2016), compared with the heterogeneity of the effects of fish oil and marine microalgae (Papadopoulos et al., 2002; Bichi et al., 2013; Toral et al., 2016b). A literature review in bovine leads to a similar conclusion (Ahnadi et al., 2002; Shingfield et al., 2003; Vahmani et al., 2014). The first reason behind this outcome might be the greater diversity in the composition of marine supplements than in that of CLA (Bichi et al., 2013; Hussein et al., 2013; Toral et al., 2015). A second reason would be that trans-10,cis-12 18:2 directly affects mammary metabolism, but responses to fish oil are largely determined by prior alterations in ruminal biohydrogenation pathways (Bauman et al., 2011; Dallaire et al., 2014; Toral et al., 2016a). Accordingly, CLA had a lower influence on milk FA profile than FO, and major changes corresponded to decreases in short- and medium-chain FA, whereas the marine lipid altered the proportion of many FA, including intermediate metabolites of ruminal biohydrogenation (e.g., trans 16- and 18-carbon FA) and hydration (8-oxo-16:0 and 10-oxo-18:0; Shingfield et al., 2010).

Milk fat depression has been described as a reduction in milk fat yield with no change in the yield of milk or other milk components (Bauman et al., 2011), a definition essentially based on the syndrome caused by trans10,cis-12 18:2 in cows (Peterson et al., 2003; Harvatine and Bauman, 2006; Dallaire et al., 2014). Hence, the diversity in the phenotypes of marine lipid-induced MFD implies that some situations do not neatly fit in the general definition, due to changes found in milk yield, as in our study, or frequent alterations in milk protein synthesis (Ahnadi et al., 2002; Shingfield et al., 2003; Toral et al., 2015). Although FO only decreased milk fat concentration and not yield, the expected downregulation of some mammary lipogenic genes (e.g., FASN or ACSS2) was only statistically significant in this treatment, supporting the idea that transcriptional control mechanisms would also be a relevant component of marine lipid-induced MFD in sheep (Carreño et al., 2016), as demonstrated for trans-10,cis-12 18:2 administration (Hussein et al., 2013; Ticiani et al., 2016).

The observed reduction in the mRNA abundance of FASN appears to be a common feature of MFD in dairy cows (Peterson et al., 2003; Gervais et al., 2009) and ewes (Hussein et al., 2013; Carreño et al., 2016). Downregulation of ACSS2 in FO may also have limited de novo FA synthesis through the potential inhibition of acetate activation, as previously suggested for this and another member of the same gene family (namely, ACSS1) in cows and sheep (Mach et al., 2011; IbeaghaAwemu et al., 2016; Toral et al., 2016b). However, the apparent lack of relationship between transcript abundance of these genes and milk concentrations of 4:0-16:0 FA seems difficult to reconcile, which merits further investigation.

Surprisingly, despite CLA-induced decreases in the concentration of de novo synthesized FA, we failed to find significant decreases in the mRNA abundance of FASN and ACSS2 in this treatment, which might be explained by statistical constrains related not only to the high inter-individual variation in gene expression (that would preclude from reaching the required $P$-level), but also to the use of multiple testing corrections. Although an effect of the dose of trans-10,cis-12 18:2 (on average, $29 \mathrm{mg} / \mathrm{kg}$ of BW) might be suspected, this was similar to the amount of the same rumen-protected product used in previous nutrigenomic studies in sheep (e.g., Hussein et al., 2013; $25 \mathrm{mg} / \mathrm{kg}$ of BW). Furthermore, the stage of lactation (on average, 102-103 DIM on d 38 and 39, when samples were collected) may have hindered the detection of significant differences at this level. Support for this has been found in a recent study in ewes showing that effects of trans-10,cis-12 18:2 on FASN transcript abundance during early- and midlactation (15 and 70 DIM, respectively) disappeared at 120 DIM (Ticiani et al., 2016).

Compared with the consistent changes between studies in the expression of enzymes responsible for de novo FA synthesis (e.g., Mach et al., 2011; Hussein et al., 2013; Carreño et al., 2016), downregulation of candidate genes involved in FA uptake and transport (i.e., $L P L$ and $F A B P 3)$ or $\Delta^{9}$-desaturation $(S C D)$ is less frequent (Ahnadi et al., 2002; Gervais et al., 2009; Mach et al., 2011), and no differences compared with the control were observed in our study. Stable expression of $L P L$ in some MFD situations (Ahnadi et al., 2002; Gervais et al., 2009; Mach et al., 2011) may be due to the fact that this gene is not necessarily a limiting factor for mammary uptake of plasma FA (Bernard et al., 2008). Moreover, LPL expression has been reported to be negatively affected in mammary epithelial cells cultured with 20:5n-3, but not with trans-10, cis-12 18:2 (Kadegowda et al., 2009), which might account for 
its lower mRNA abundance in FO than in CLA. Regarding $F A B P 3$, less information about its nutritional regulation is available in ruminants, and although its expression decreased with trans-10,cis-12 18:2 in vitro (Kadegowda et al., 2009) and with fish oil supplementation in vivo (Carreño et al., 2016), the lack of variation in other studies may suggest no relationship with MFD (Invernizzi et al., 2010; Bichi et al., 2013; Hussein et al., 2013). Similarly, information about the role of $S C D$ in the low milk-fat syndrome is inconsistent, with reductions, lack of changes, or even increases (Harvatine and Bauman, 2006; Invernizzi et al., 2010; Carreño et al., 2016) in its expression, which could be attributed to its complex nutritional regulation and the mediation of posttranscriptional control mechanisms (Bernard et al., 2008). In our study, differences between FO and CLA in the milk proportion of cis-9 10:1, cis-9 18:1, and cis-9,trans-11 18:2 (products of the SCD enzyme) would likely be independent of transcriptional mechanisms (given the close $S C D$ mRNA abundances in both treatments) and more related to concomitant variations in 10:0, 18:0, and trans-11 18:1 concentration (their respective substrates for $\Delta^{9}$-desaturation).

Fatty acids derived from these 3 metabolic pathways (de novo synthesis, uptake and transport, and desaturation) are mostly incorporated into triacylglycerols before being secreted in milk fat globules. Among the enzymes responsible for FA esterification to glycerol, MFD is often accompanied by stable transcript abundances of GPAM (Angulo et al., 2012; Hussein et al., 2013; Carreño et al., 2016), in agreement with our observations. Interestingly, dietary treatments showed clear differences in the expression of LPIN1 (downregulated in FO) and GPAT 4 (upregulated in CLA), which might suggest unequal roles and regulation in MFD. On the one hand, downregulation of LPIN1 agrees with data from MFD induced by fish oil and soybean oil in cows (Invernizzi et al., 2010) and might have limited the rate of triacylglycerol synthesis (Takeuchi and Reue, 2009), contributing to decrease milk fat concentration in FO. On the other hand, the implications of GPAT4 upregulation in CLA are not evident, and could hardly be associated with the effects of this supplement on milk fat concentration or FA profile. The greater mRNA abundance of this gene is consistent with the effect of trans10,cis-12 18:2 in vitro (Kadegowda et al., 2009), but contrasts with results in lactating sheep (Hussein et al., 2013). In our study, changes in GPAT4 expression were similar to variations in transcriptional factors (such as PPARG) due to trans-10,cis-12 18:2 supplementation. In fact, PPARG, which regulates GPAT4 (Kadegowda et al., 2009; Shi et al., 2014), showed increased mRNA abundance in the CLA treatment. This transcription factor can be activated by endogenous agonists, such as certain FA (Bionaz et al., 2015), but trans-10, cis-12 18:2 appears to be a weaker activator compared with some SFA (i.e., 16:0 and 18:0; Kadegowda et al., 2009) that were not affected by CLA in our assay. Still, regardless of the cause of its upregulation in CLA and despite its prominent role in milk fat synthesis (Kadegowda et al., 2009; Shi et al., 2014), the literature shows no clear support for a PPARG-dependent mechanism in CLAinduced MFD (Ma et al., 2014; Bionaz et al., 2015).

Likewise, a direct involvement in this syndrome of $N R 1 H 3$, a factor that followed a parallel trend (see Figures 1 and 2), has recently been dismissed (Harvatine et al., 2014; Ma et al., 2014). Consequently, its observed upregulation with the CLA diet might have been related to other aspects of lipid metabolism that were not examined in our case, such as cholesterol homeostasis (Ontsouka and Albrecht, 2014; Bionaz et al., 2015). This would be consistent with the upregulation with CLA of $A B C G 1$, a gene with a potential role in milk cholesterol secretion (Ontsouka and Albrecht, 2014). With respect to FO, the little available information on the nutritional regulation of mammary $N R 1 H 3$ and $A B C G 1$ expression in ruminants includes no effects of fish oil supplementation in the former (Toral et al., 2013) and downregulation of the latter with trans-10, cis-12 18:2 (Hussein et al., 2013), but further research would be necessary to better characterize their response to dietary treatments. Furthermore, although NR1H3 would not directly participate in trans-10,cis-12 18:2-induced MFD (Harvatine et al., 2014; Ma et al., 2014), several studies have reported that it may control the mammary expression of SREBF1 (Harvatine et al., 2014; Bionaz et al., 2015), leaving room for speculation about an indirect relationship with the nutritional regulation of mammary lipogenesis. Indeed, SREBF1 is a central regulator of milk fat synthesis and its role in MFD appears crucial (Bernard et al., 2008; Bauman et al., 2011; Bionaz et al., 2015). Therefore, the lack of variation in its mRNA abundance in FO and CLA treatments was unexpected and contrasts with most reports on MFD in lactating ruminants (Angulo et al., 2012; Hussein et al., 2013; Carreño et al., 2016). However, as discussed above for FASN, Ticiani et al. (2016) reported that downregulation of SREBF1 during CLA-induced MFD could not be detected at a relatively advanced stage of lactation in ewes, which would contribute to explain our results (on average, 102-103 DIM when the samples were collected).

Finally, consistent with $S R E B F 1$ results, no clear association was found between INSIG1 and MFD, as mRNA abundances in FO and CLA were not statistically different from those in the control. Nevertheless, significant variations between FO and CLA treatments in this transcription factor and the fact that it codes 
for a SREBP1 regulatory protein (Bauman et al., 2011; Bionaz et al., 2015) might point to responses to each supplement being not mediated by the same transcriptional mechanisms. In any event, care must be taken before withdrawing conclusions on this subject, because genes other than those quantified in our trial may have relevant roles in MFD. It is indeed expected that the increasing application of high-throughput technologies allowing examination of the whole mammary transcriptome (Wickramasinghe et al., 2012; Suárez-Vega et al., 2015) will be very useful for candidate gene selection in forthcoming nutrigenomic studies.

\section{CONCLUSIONS}

Direct comparison of the effects of FO and CLA on milk composition and mammary candidate gene expression suggests that there might be relevant differences in the transcriptional control mechanisms underlying the response to each lipid supplement. The phenotype of the trans-10,cis-12 18:2-induced MFD was consistent with the literature, but expected effects on the mRNA abundance of some candidate genes (e.g., FASN or SREBF1) could not be detected in this study. This might be explained, at least to some extent, by the relatively advanced lactation stage (on average, 102-103 DIM when samples were collected for analysis). Furthermore, significant differences in the mRNA abundance of lipogenic genes such as ACSS2, FASN and LPIN1 were observed in the treatment with FO, supporting the hypothesis that transcriptional regulation would be a relevant component of marine lipid-induced MFD in sheep.

\section{ACKNOWLEDGMENTS}

This work was supported by the Spanish Ministry of Economy and Competitiveness (MINECO; AGL201454587, co-funded by the European Regional Development Fund). P. G. Toral gratefully acknowledges receipt of a postdoctoral research contract from the MINECO (Juan de la Cierva program). The authors thank Y. Chilliard, L. Bernard, C. Leroux (INRA, ClermontFerrand, France), and J. J. Arranz and A. Suárez-Vega (University of León, Spain), for helpful assistance with nutrigenomic techniques.

\section{REFERENCES}

Ahnadi, C. E., N. Beswick, L. Delbecchi, J. J. Kennelly, and P. Lacasse. 2002. Addition of fish oil to diets for dairy cows. II. Effects on milk fat and gene expression of mammary lipogenic enzymes. J. Dairy Res. 69:521-531.

Angulo, J., L. Mahecha, K. Nuernberg, G. Nuernberg, D. Dannenberger, M. Olivera, M. Boutinaud, C. Leroux, E. Albrecht, and L.
Bernard. 2012. Effects of polyunsaturated fatty acids from plant oils and algae on milk fat yield and composition are associated with mammary lipogenic and SREBF1 gene expression. Animal 6:1961-1972.

Bauman, D. E., K. J. Harvatine, and A. L. Lock. 2011. Nutrigenomics, rumen-derived bioactive fatty acids, and the regulation of milk fat synthesis. Annu. Rev. Nutr. 31:299-319.

Bernard, L., C. Leroux, and Y. Chilliard. 2008. Expression and nutritional regulation of lipogenic genes in the ruminant lactating mammary gland. Adv. Exp. Med. Biol. 606:67-108.

Bichi, E., P. Frutos, P. G. Toral, D. Keisler, G. Hervás, and J. J. Loor. 2013. Dietary marine algae and its influence on tissue gene network expression during milk fat depression in dairy ewes. Anim. Feed Sci. Technol. 186:36-44.

Bionaz, M., and J. J. Loor. 2007. Identification of reference genes for quantitative real-time PCR in the bovine mammary gland during the lactation cycle. Physiol. Genomics 29:312-319.

Bionaz, M., J. Osorio, and J. J. Loor. 2015. Nutrigenomics in dairy cows: Nutrients, transcription factors, and techniques. J. Anim. Sci. 93:5531-5553.

Bonnet, M., L. Bernard, S. Bes, and C. Leroux. 2013. Selection of reference genes for quantitative real-time PCR normalisation in adipose tissue, muscle, liver and mammary gland from ruminants. Animal 7:1344-1353.

Carreño, D., G. Hervás, P. G. Toral, T. Castro-Carrera, and P. Frutos. 2016. Fish oil-induced milk fat depression and associated downregulation of mammary lipogenic genes in dairy ewes. J. Dairy Sci. 99:7971-7981.

Castro-Carrera, T., P. Frutos, C. Leroux, Y. Chilliard, G. Hervás, A. Belenguer, L. Bernard, and P. G. Toral. 2015. Dietary sunflower oil modulates milk fatty acid composition without major changes in adipose and mammary tissue fatty acid profile or related gene mRNA abundance in sheep. Animal 9:582-591.

Chilliard, Y., F. Glasser, A. Ferlay, L. Bernard, J. Rouel, and M. Doreau. 2007. Diet, rumen biohydrogenation and nutritional quality of cow and goat milk fat. Eur. J. Lipid Sci. Technol. 109:828 855.

Dallaire, M. P., H. Taga, L. Ma, B. A. Corl, R. Gervais, Y. Lebeuf, F. J. Richard, and P. Y. Chouinard. 2014. Effects of abomasal infusion of conjugated linoleic acids, Sterculia foetida oil, and fish oil on production performance and the extent of fatty acid $\Delta^{9}$ desaturation in dairy cows. J. Dairy Sci. 97:6411-6425.

Gervais, R., J. W. McFadden, A. J. Lengi, B. A. Corl, and P. Y. Chouinard. 2009. Effects of intravenous infusion of trans-10, cis-12 18:2 on mammary lipid metabolism in lactating dairy cows. J. Dairy Sci. 92:5167-5177.

Gonzalo, C., J. A. Carriedo, J. D. Gomez, L. D. Gomez, and F. San Primitivo. 1994. Diurnal variation in the somatic cell count of ewe milk. J. Dairy Sci. 77:1856-1859.

Harvatine, K. J., and D. E. Bauman. 2006. SREBP1 and thyroid hormone responsive spot 14 (S14) are involved in the regulation of bovine mammary lipid synthesis during diet-induced milk fat depression and treatment with CLA. J. Nutr. 136:2468-2474.

Harvatine, K. J., Y. R. Boisclair, and D. E. Bauman. 2014. Liver x receptors stimulate lipogenesis in bovine mammary epithelial cell culture but do not appear to be involved in diet-induced milk fat depression in cows. Physiol. Rep. 2:e00266.

Hussein, M., K. H. Harvatine, W. M. P. B. Weerasinghe, L. A. Sinclair, and D. E. Bauman. 2013. Conjugated linoleic acid-induced milk fat depression in lactating ewes is accompanied by reduced expression of mammary genes involved in lipid synthesis. J. Dairy Sci. 96:3825-3834.

Ibeagha-Awemu, E. M., R. Li, A. A. Ammah, P. L. Dudemaine, N. Bissonnette, C. Benchaar, and X. Zhao. 2016. Transcriptome adaptation of the bovine mammary gland to diets rich in unsaturated fatty acids shows greater impact of linseed oil over safflower oil on gene expression and metabolic pathways. BMC Genomics 17:104.

Invernizzi, G., B. J. Thering, M. A. McGuire, G. Savoini, and J. J. Loor. 2010. Sustained upregulation of stearoyl-CoA desaturase in bovine mammary tissue with contrasting changes in milk fat syn- 
thesis and lipogenic gene networks caused by lipid supplements. Funct. Integr. Genomics 10:561-575.

ISO. 1999a. Animal feeding stuffs-Determination of moisture and other volatile matter content. Standard 6496:1999. International Organisation for Standardisation (ISO), Geneva, Switzerland.

ISO. 1999b. Whole milk-Determination of milk fat, protein and lactose content-Guidance on the operation of mid-infrared instruments. Standard 9622:1999. International Organisation for Standardisation (ISO), Geneva, Switzerland.

ISO. 2002. Animal feeding stuffs - Determination of crude ash. Standard 5984:2002. International Organisation for Standardisation (ISO), Geneva, Switzerland.

ISO. 2009. Animal feeding stuffs-Determination of nitrogen content and calculation of crude protein content-Part 2: Block digestion and steam distillation method. Standard 5983-2:2009. International Organisation for Standardisation (ISO), Geneva, Switzerland.

Kadegowda, A. K. G., M. Bionaz, L. S. Piperova, R. A. Erdman and J. J. Loor. 2009. Peroxisome proliferator-activated receptorgamma activation and long-chain fatty acids alter lipogenic gene networks in bovine mammary epithelial cells to various extents. J. Dairy Sci. 92:4276-4289.

Keady, T. W. J., C. S. Mayne, and D. A. Fitzpatrick. 2000. Effects of supplementation of dairy cattle with fish oil on silage intake, milk yield and milk composition. J. Dairy Res. 67:137-153.

Ma, L., A. J. Lengi, M. L. McGilliard, D. E. Bauman, and B. A. Corl. 2014. Short communication: Effect of trans-10,cis-12 conjugated linoleic acid on activation of lipogenic transcription factors in bovine mammary epithelial cells. J. Dairy Sci. 97:5001-5006.

Mach, N., A. A. A. Jacobs, L. Kruijt, J. van Baal, and M. A. Smits. 2011. Alteration of gene expression in mammary gland tissue of dairy cows in response to dietary unsaturated fatty acids. Animal $5: 1217-1230$.

Mele, M., A. Buccioni, F. Petacchi, A. Serra, S. Banni, M. Antongiovanni, and P. Secchiari. 2006. Effect of forage/concentrate ratio and soybean oil supplementation on milk yield, and composition from Sarda ewes. Anim. Res. 55:273-285.

Ontsouka, E. C., and C. Albrecht. 2014. Cholesterol transport and regulation in the mammary gland. J. Mammary Gland Biol. Neoplasia 19:43-58

Papadopoulos, G., C. Goulas, E. Apostolaki, and R. Abril. 2002. Effects of dietary supplements of algae, containing polyunsaturated fatty acids, on milk yield and the composition of milk products in dairy ewes. J. Dairy Res. 69:357-365.

Peterson, D. G., E. A. Matitashvili, and D. E. Bauman. 2003. Diet-induced milk fat depression in dairy cows results in increased trans-10, cis-12 CLA in milk fat and coordinate suppression of mRNA abundance for mammary enzymes involved in milk fat synthesis. J. Nutr. 133:3098-3102.

Shi, H. B., W. S. Zhao, J. Luo, D. W. Yao, Y. T. Sun, J. Li, H. P. Shi, and J. J. Loor. 2014. Peroxisome proliferator-activated receptor $\gamma 1$ and $\gamma 2$ isoforms alter lipogenic gene networks in goat mammary epithelial cells to different extents. J. Dairy Sci. 97:5437-5447.
Shingfield, K. J., S. Ahvenjärvi, V. Toivonen, A. Äröla, K. V. V. Nurmela, P. Huhtanen, and J. M. Griinari. 2003. Effect of dietary fish oil on biohydrogenation of fatty acids and milk fatty acid content in cows. Anim. Sci. 77:165-179.

Shingfield, K. J., L. Bernard, C. Leroux, and Y. Chilliard. 2010. Role of trans fatty acids in the nutritional regulation of mammary lipogenesis in ruminants. Animal 4:1140-1166.

Suárez-Vega, A., B. Gutiérrez-Gil, C. Klopp, C. Robert-Granie, G. Tosser-Klopp, and J. J. Arranz. 2015. Characterization and comparative analysis of the milk transcriptome in two dairy sheep breeds using RNA sequencing. Sci. Rep. 5:18399.

Sukhija, P. S., and D. L. Palmquist. 1988. Rapid method for determination of total fatty-acid content and composition of feedstuffs and feces. J. Agric. Food Chem. 36:1202-1206.

Takeuchi, K., and K. Reue. 2009. Biochemistry, physiology, and genetics of GPAT, AGPAT, and lipin enzymes in triglyceride synthesis. Am. J. Physiol. Endocrinol. Metab. 296:E1195-E1209.

Ticiani, E., M. Urio, R. Ferreira, K. J. Harvatine, and D. E. De Oliveira. 2016. Transcriptional regulation of acetyl-CoA carboxylase $\alpha$ isoforms in dairy ewes during conjugated linoleic acid induced milk fat depression. Animal 10:1677-1683.

Toral, P. G., L. Bernard, C. Delavaud, D. Gruffat, C. Leroux, and Y. Chilliard. 2013. Effects of fish oil and additional starch on tissue fatty acid profile and lipogenic gene mRNA abundance in lactating goats fed a diet containing sunflower-seed oil. Animal 7:948-956.

Toral, P. G., G. Hervás, D. Carreño, A. Belenguer, and P. Frutos 2015. Comparison of milk fatty acid responses during fish oil- and trans-10 cis-12 18:2-induced milk fat depression in dairy ewes. Anim. Feed Sci. Technol. 210:66-73.

Toral, P. G., G. Hervás, D. Carreño, and P. Frutos. 2016a. Does supplemental 18:0 alleviate fish oil-induced milk fat depression in dairy ewes? J. Dairy Sci. 99:1133-1144.

Toral, P. G., G. Hervás, P. Gómez-Cortés, P. Frutos, M. Juárez, and M. A. de la Fuente. 2010. Milk fatty acid profile and dairy sheep performance in response to diet supplementation with sunflower oil plus incremental levels of marine algae. J. Dairy Sci. 93:1655-1667.

Toral, P. G., G. Hervás, A. Suárez-Vega, J. J. Arranz, and P. Frutos. 2016b. Isolation of RNA from milk somatic cells as an alternative to biopsies of mammary tissue for nutrigenomic studies in dairy ewes. J. Dairy Sci. 99:8461-8471.

Vahmani, P., K. E. Glover, and A. H. Fredeen. 2014. Effects of pasture versus confinement and marine oil supplementation on the expression of genes involved in lipid metabolism in mammary, liver, and adipose tissues of lactating dairy cows. J. Dairy Sci. 97:4174-4183.

Vandesompele, J., K. De Preter, F. Pattyn, B. Poppe, N. Van Roy, A. De Paepe, and F. Speleman. 2002. Accurate normalization of real-time quantitative RT-PCR data by geometric averaging of multiple internal control genes. Genome Biol. 3:RESEARCH0034.

Wickramasinghe, S., G. Rincon, A. Islas-Trejo, and J. F. Medrano. 2012. Transcriptional profiling of bovine milk using RNA sequencing. BMC Genomics 13:45. 